\title{
Effect of Irrigation Intervals and Shading on Growth Quality of Beaucarnea recurvata Plants

\author{
Nader A. El-Shanhorey ${ }^{1}$ and Mona A. Sorour ${ }^{2}$
}

\begin{abstract}
The present study was carried-out at Antoniades Research Branch, Horticultural Research Institute, A.R.C. Alexandria, Egypt, during the two successive seasons of 2017 and 2018. The aim of this study was to evaluate the effects of different irrigation intervals and shading treatments on growth quality of Beaucarnea recurvata plants grown in mixture soil of sand and clay1:1(v/v). An experiment was established to test the effect of four irrigation intervals $(7,14,21$ and 28 days) and one irrigation level was used to keep the soil moisture at the field capacity of the mixture soil at $100 \%$, in addition to three levels of shading $(0,30$, and $60 \%)$. Data showed that the lowest irrigation intervals (7days) had given the highest results, while shading $(30 \%)$ had given the highest effects on the vegetative growth and chemical constituents. Regarding the interaction between effect of irrigation intervals and different shading treatments on the vegetative growth and chemical constituents, the results showed that the highest mean values in the number of leaves, leaves dry weights, leaves area, stem diameter, caudex diameter, stem dry weight, caudex dry weight, root length, root dry weight, carbohydrates, Nitrogen, Phosphorus and Potassium, were obtained in irrigation intervals (7 days) and shading (30\%). While, the results showed that the greatest plant height and total chlorophylls, were obtained in irrigation intervals (7 days) and shading $(60 \%)$. In addition, the highest proline content were obtained in irrigation intervals ( 28 days) and shading $(0 \%)$ and highest relative water content were obtained in irrigation intervals (28 days) and shading (60\%).
\end{abstract}

Key words: Beaucarnea recurvata - Irrigation intervals - Shading.

\section{INTRODUCTION}

Beaucarnea recurvata is a plant with a confused identity. It is one of seven species in the genus Beaucarnea. The group has been included in the family Asparagaceae. Regardless of its taxonomic designation, this group of small tropical trees is native to Mexico, Brazil and Guatemala. Ponytail palm, Beaucarnea recurvata (or Nolina recurvata) from semi-desert areas of southeastern Mexico, is the species often grown as a low-maintenance houseplant in temperate climates, as well as being used as a landscape specimen in dry, warm climates. This plant can grow to 30 feet tall, but in containers remains much shorter. Its trunk has a flared, enlarged base (a globose caudex) suggestive of an elephant's foot. The caudex can eventually get up to 12 feet across, and often develops fissures or crackles on the gray surface, furthering the pachyderm comparison. The swollen trunk serves to store water, allowing the plant to survive extended droughts. It begins with a single stem, but will branch with age and after flowering. The plants also will branch if broken off or cut when small (less than 6 inch diameter); growers of ornamental plants often do this while plants are dormant in order to produce three-headed plants. The evergreen leaves are long and strap- or grasslike. On mature plants they can be up to six feet long and only an inch wide, but are much shorter on smaller plants. They are rather tough and leathery, with very finely serrated edges sharp enough to cut skin. The rosette of leaves emanates from the top of the trunk or ends of the branches, and gracefully cascade down like a green fountain. On many plants the leaves twist or curl slightly when longer, giving the plant an interesting, flowing look. Older leaves eventually turn yellow and dry up; these can be removed (Rivera-Lugo \& Solano, 2012).

One of the most important factors affecting plant growth and production of secondary metabolites is water supply (Randhawa et al., 1992). Flevas and Medrano (2002) mentioned that moisture deficiency induces various physiological and metabolic responses like stomatal closure and decline in growth rate and photosynthesis. Water supply is an important factor affecting growth and metabolic activities in plant species. It has generally negative effect on plant growth and development. However, there are reports on the positive effect of limited water supply, as far as the biosynthesis of secondary metabolites, enzyme activities and solute accumulation is concerned (Singh-Sangwan et al., 2001). Water deficit is a limiting factor in the production of many field crops, as well as water stress

DOI: 10.21608 /ASEJAIQJSAE.2019.68842

${ }^{1}$ Botanical Gardens Research Department, Horticulture Research Institute, Agricultural Research Center, Alexandria, Egypt.

${ }^{2}$ Ornamental Plants Research Department, Horticulture Research Institute, Agricultural Research Center, Alexandria, Egypt.

Received November 28, 2019, Accepted December 29, 2019 
causes different morphological, physiological and biochemical changes including leaf area reduction, leaf senescence and reduction in cell development (Kafi and Damghani, 2001). Also, drought led to biochemical disorders and can change plant behaviors regarding the biosynthesis of primary and secondary metabolites. Lipids are vital to cell functions and plasma membrane may be the primary site of drought damage and it has been shown that water deficit results in a great modifications of membrane fatty acid composition in many crops (Laribi et al., 2009, Bettaieb et al., 2011; Bourgou et al., 2011).

Shading nets are used in tropical and subtropical countries for vegetable production (Castellano et al., 2008, Ilic et al., 2012 and Kittas et al., 2012). There is, however, little information on use of shading for vegetable production in the southeast United States over the past 40 years (Boyhan et al., 2008). Studies showed that shading increases plant growth and yield in bell pepper (Rylski and Spigelman, 1986). Shading also reduces water requirements and increases irrigation water use efficiency in peppers. The study evaluated the effects of shade level on the bell pepper crop microenvironment, plant growth, leaf gas exchange, and mineral nutrient content (Moller and Assouline, 2007).

Shading also reduces water requirements and increases irrigation water use efficiency (Moller and Assouline, 2007). Thus, the aim of this work was to evaluate Beaucarnea recurvata plants under different irrigation intervals and different levels of shading.

\section{MATERIAL AND METHODS}

The present study was carried-out at Antoniades Research Branch, Horticultural Research Institute, A.R.C. Alexandria, Egypt, during two successive seasons of 2017 and 2018. The aim of this study was to evaluate the effects of different irrigation intervals and shading treatments on growth quality of Beaucarnea recurvata plants grown in mixture soil under the circumstances of Alexandria.

On the $15^{\text {th }}$ of February 2017 and 2018 in the first and second seasons, respectively, homogeneous seedlings of Beaucarnea recurvata $(48-52 \mathrm{~cm}$ height and with number of leaves $20-25$ per plant) were planted individually in plastic pots $(20 \mathrm{~cm}$ diameter) filled with $7 \mathrm{~kg}$ of mixture of sand and clayl:1(v/v). The chemical constituents of the soil were measured as described by Jackson (1958) and presented in Table (A). On the $1^{\text {st }}$ of March in the first and second seasons, the irrigation intervals and shading treatments were initiated. On $30^{\text {th }}$ of October in both seasons, the data on Beaucarnea recurvata plants were calculated.

Tap water was used as a source of irrigation water. Four irrigation intervals were used and one irrigation level was used to keep the soil moisture at the field capacity of the mixture soil at $100 \%$. The moisture level was determined by using Moisture Tester Model KS-DI (Gypsum Block) during growing season. At the end of the experiment, the total amount of irrigation water for each pot was calculated and presented in Table (B), as described by Israelsen and Hansen (1962).

Table A. Some chemical analyses of the used mixture soil for the two successive seasons 2017 and 2018.

\begin{tabular}{lccccccccc}
\hline Season & $\mathbf{p H}$ & $\mathbf{E C}$ & \multicolumn{3}{c}{ Soluble cations (meq/l) } & \multicolumn{3}{c}{ Soluble anions (meq/l) } \\
\cline { 3 - 9 } & & $\left(\mathbf{d S m}^{-\mathbf{1}}\right)$ & $\mathbf{C a}^{++}$ & $\mathbf{M g}^{++}$ & $\mathbf{N a}^{+}$ & $\mathbf{K}^{+}$ & $\mathbf{H C O}_{3}^{-}$ & $\mathbf{C l}^{-}$ & $\mathbf{S O}_{2}^{--}$ \\
\hline 2017 & 8.08 & 2.53 & 18.20 & 14.20 & 23.91 & 4.49 & 7.20 & 21.00 & 27.10 \\
2018 & 8.13 & 2.03 & 13.22 & 3.0 & 16.21 & 3.79 & 6.52 & 16.93 & 25.21 \\
\hline
\end{tabular}

Table B. Total amount of the water used $100 \%$ field capacity for each plant $(\mathrm{L} /$ pot $)$ in each treatment during the growing two seasons of 2017 and 2018.

\begin{tabular}{|c|c|c|c|c|c|c|c|c|c|c|}
\hline \multirow{2}{*}{$\begin{array}{l}\text { Irrigation } \\
\text { intervals } \\
\text { (day) }\end{array}$} & \multirow{2}{*}{$\begin{array}{c}\text { Shading } \\
\text { levels } \\
(\%)\end{array}$} & \multicolumn{9}{|c|}{ Months of the first and second seasons } \\
\hline & & March & April & May & June & July & August & September & October & Total \\
\hline \multirow{3}{*}{7} & $0 \%$ & 4.00 & 4.00 & 6.25 & 5.00 & 6.00 & 7.50 & 5.00 & 5.00 & 42.75 \\
\hline & $30 \%$ & 3.80 & 3.80 & 6.05 & 4.80 & 5.80 & 7.30 & 4.80 & 4.80 & 41.15 \\
\hline & $60 \%$ & 3.60 & 3.60 & 5.85 & 4.60 & 5.60 & 7.10 & 4.60 & 4.60 & 39.55 \\
\hline \multirow{3}{*}{14} & $0 \%$ & 2.00 & 2.00 & 2.50 & 2.50 & 3.00 & 4.50 & 2.50 & 2.00 & 21.00 \\
\hline & $30 \%$ & 1.85 & 1.85 & 2.35 & 2.35 & 2.85 & 4.35 & 2.35 & 1.85 & 19.80 \\
\hline & $60 \%$ & 1.70 & 1.70 & 2.20 & 2.20 & 2.70 & 4.20 & 2.20 & 1.70 & 18.60 \\
\hline \multirow{3}{*}{21} & $0 \%$ & 1.00 & 1.00 & 2.50 & 1.25 & 3.00 & 1.50 & 2.50 & 1.00 & 13.75 \\
\hline & $30 \%$ & 0.90 & 0.90 & 2.40 & 1.15 & 2.90 & 1.40 & 2.40 & 0.90 & 12.95 \\
\hline & $60 \%$ & 0.80 & 0.80 & 2.30 & 1.05 & 2.80 & 1.30 & 2.30 & 0.80 & 12.15 \\
\hline \multirow{3}{*}{28} & $0 \%$ & 1.00 & 1.00 & 1.25 & 1.25 & 1.50 & 1.50 & 1.25 & 1.00 & 9.75 \\
\hline & $30 \%$ & 0.95 & 0.95 & 1.20 & 1.20 & 1.45 & 1.45 & 1.20 & 0.95 & 9.35 \\
\hline & $60 \%$ & 0.90 & 0.90 & 1.15 & 1.15 & 1.40 & 1.40 & 1.15 & 0.90 & 8.95 \\
\hline
\end{tabular}


Shading was created by nets which reduced the incoming solar radiation by $30 \%$ and $60 \%$. The die rent shading levels were compared with full sunlight $(0 \%$ shade). The nets were made of polyethylene and were green and had different mesh sizes to create the different shading levels. Nets were installed at the start of irrigation treatments, on $1^{\text {st }}$ March in the first and second seasons, respectively. Nets were clipped on to steel wires, which were connected between wooden posts. The height of the nets could be adapted to the plant growth, and was 1.5 meter in height. A distance of 0.5 $\mathrm{m}$ between the plants and canopy surface was guaranteed. Table (C) shows the total incoming daily solar irradiance at the experimental site from the start of treatments for each experimental year and the theoretically reduced incoming total solar irradiance under the shading nets.

In both seasons, all plants received NPK chemical fertilization using soluble fertilizer (Milagro Aminoleaf 20-20-20) at the rate of $2 \mathrm{~g} /$ pot. Fertilization was repeated every 28 days throughout the growing season (from the $15^{\text {th }}$ of March till the $30^{\text {th }}$ of October). In addition, weeds were removed manually upon emergence.

\section{Data recorded}

\section{(1) Vegetative growth parameters:}

Plant height $(\mathrm{cm})$, leaves number per plant, leaves area $\left(\mathrm{cm}^{2}\right)$ according to Koller (1972), leaves dry weight per plant $(\mathrm{g})$, stem diameter $(\mathrm{cm})$, Caudex diameter $(\mathrm{cm})$, stem dry weight $(\mathrm{g})$, Caudex dry weight $(\mathrm{g})$, root length $(\mathrm{cm})$ and root dry weight $(\mathrm{g})$.

\section{(2) Chemical analyses:}

-Chlorophyll contents were determined as SPAD unit in the fresh leaves of plants for the different treatments under the experiment at the end of the season using Minolta (chlorophyll meter) SPAD 502 according to Yadava (1986).

-Carbohydrate contents of the leaves were determined according to Dubios et al.(1956).

-Relative water content of leaves (\%) in the fresh leaves was determined according to Barrs (1968) and Ritchie (1974).
-Proline content (\% of dry matter) in the leaves was determined according to Bates et al., (1973).

- Nitrogen, phosphorus and potassium in the leaves were determined according to the methods described by Allen (1959), Jackson (1962) and Champman and Pratt (1961), respectively.

The experimental design was split plot with three replicates. Each replicate contained three plants. The main plot was irrigation intervals concentration, while the subplot was shading treatments. Data were subjected to analysis of variance (ANOVA) using the SAS program (SAS Institute, 2002). The Means of the individual factors and their interactions were compared by L.S.D test at $5 \%$ level of probability according to Snedecor and Cochran (1989).

\section{RESULTS}

\section{Plant height and leaves characteristics:}

Data presented in Table (1) showed that the lowest irrigation intervals (7days) gave the highest plant height $(70.38$ and $81.60 \mathrm{~cm})$, as well as each of the number of leaves (46.66 and 54.05 leaves per plant), leaves dry weights (3.35 and $3.88 \mathrm{~g})$ and leaves area (1418.77 and $1680.50 \mathrm{~cm}^{2}$ ) in the first and second seasons, respectively. On the other hand, the highest irrigation intervals (28days) produced the lowest plant height $(65.44$ and $76.49 \mathrm{~cm})$, each of the number of leaves (43.22 and 50.66 leaves per plant), leaves dry weight (3.11 and $3.64 \mathrm{~g}$ ) and leaves area (981.23 and 1149.95 $\mathrm{cm}^{2}$ ) in the first and second seasons, respectively.

Also, the data presented in Table (1) showed that, the different shading treatments had a significant effect on Beaucarnea recurvata plants. Shading (60\%) gave the highest plant height $(69.99$ and $80.91 \mathrm{~cm})$ and shading $(30 \%)$ had given the highest number of leaves (46.25 and 53.45 leaves per plant), leaves dry weights (3.33 and $3.84 \mathrm{~g})$ and leaves area (1261.08 and 1457.32 $\mathrm{cm}^{2}$ ) in the first and second seasons, respectively, compared with control plants shading $(0 \%)$ that recorded the lowest plant height $(65.91$ and $78.87 \mathrm{~cm})$,

Table C. The calculated total solar irradiance for the shading treatments (Lux) during the without shading, the $30 \%$ with shading and the $60 \%$ with shading, in the two seasons 2017 and 2018.

\begin{tabular}{lcccccccc}
\hline $\begin{array}{l}\text { Shading levels } \\
(\%)\end{array}$ & March & April & May & June & July & August & September & October \\
\cline { 2 - 9 } & 5720 & 6710 & 7590 & 8750 & 10460 & 12210 & 11590 & 9130 \\
\hline $0 \%$ & 4510 & 4830 & 5670 & 5830 & 6970 & 8140 & 7960 & 6090 \\
\hline $30 \%$ & 2340 & 2400 & 2980 & 2910 & 3480 & 4080 & 4490 & 3080 \\
\hline $60 \%$ & & & & & &
\end{tabular}


Table 1. Means of plant height $(\mathrm{cm})$, number of leaves per plant, leaves dry weight $(\mathrm{g})$ and leaves area $\left(\mathrm{cm}^{2}\right)$ of Beaucarnea recurvata plants as influenced by irrigation intervals (Irr. In.), shading (Sh.) and their interactions (Irr. In. $\times$ Sh.) in the two seasons of 2017 and 2018.

\begin{tabular}{|c|c|c|c|c|c|c|c|c|c|}
\hline \multicolumn{2}{|c|}{ Treatments } & \multicolumn{2}{|c|}{$\begin{array}{l}\begin{array}{l}\text { Plant height } \\
(\mathrm{cm})\end{array} \\
\end{array}$} & \multicolumn{2}{|c|}{$\begin{array}{c}\text { Number of leaves } \\
\text { per plant }\end{array}$} & \multicolumn{2}{|c|}{$\begin{array}{l}\text { Leaves dry weight } \\
\text { (g) }\end{array}$} & \multicolumn{2}{|c|}{$\begin{array}{c}\text { Leaves area } \\
\left(\mathrm{cm}^{2}\right)\end{array}$} \\
\hline $\begin{array}{l}\text { Irrigation } \\
\text { intervals } \\
\text { (day) }\end{array}$ & $\begin{array}{c}\text { Shading } \\
(\%)\end{array}$ & 2017 & 2018 & 2017 & 2018 & 2017 & 2018 & 2017 & 2018 \\
\hline \multirow{3}{*}{7 days } & $0 \%$ & 68.66 & 80.16 & 46.83 & 53.00 & 3.37 & 3.82 & 1469.16 & 1693.98 \\
\hline & $30 \%$ & 70.66 & 81.66 & 47.50 & 54.83 & 3.42 & 3.95 & 1518.11 & 1754.98 \\
\hline & $60 \%$ & 71.83 & 83.00 & 45.66 & 54.33 & 3.27 & 3.89 & 1269.05 & 1592.54 \\
\hline \multicolumn{2}{|c|}{ Mean (Irr. In.) } & 70.38 & 81.60 & 46.66 & 54.05 & 3.35 & 3.88 & 1418.77 & 1680.50 \\
\hline & $0 \%$ & 64.33 & 80.50 & 46.83 & 54.00 & 3.36 & 3.88 & 1277.62 & 1445.84 \\
\hline \multirow[t]{2}{*}{14 days } & $30 \%$ & 70.66 & 81.50 & 47.00 & 54.33 & 3.37 & 3.90 & 1306.27 & 1507.94 \\
\hline & $60 \%$ & 70.83 & 82.00 & 42.50 & 53.33 & 3.06 & 3.83 & 1217.47 & 1448.52 \\
\hline \multicolumn{2}{|c|}{ Mean (Irr. In.) } & 68.60 & 81.33 & 45.44 & 53.88 & 3.26 & 3.87 & 1267.12 & 1467.43 \\
\hline \multirow{3}{*}{21 days } & $0 \%$ & 67.33 & 80.00 & 44.50 & 53.83 & 3.20 & 3.86 & 1121.42 & 1356.63 \\
\hline & $30 \%$ & 67.83 & 80.16 & 46.50 & 53.16 & 3.37 & 3.82 & 1181.11 & 1350.45 \\
\hline & $60 \%$ & 70.66 & 81.00 & 44.83 & 53.16 & 3.23 & 3.81 & 1090.79 & 1293.54 \\
\hline \multicolumn{2}{|c|}{ Mean (Irr. In.) } & 68.60 & 80.38 & 45.27 & 53.38 & 3.26 & 3.83 & 1131.10 & 1333.54 \\
\hline & $0 \%$ & 63.33 & 74.83 & 43.83 & 51.00 & 3.16 & 3.67 & 1012.98 & 1178.61 \\
\hline \multirow[t]{2}{*}{28 days } & $30 \%$ & 66.33 & 77.00 & 44.00 & 51.50 & 3.17 & 3.70 & 1038.84 & 1215.91 \\
\hline & $60 \%$ & 66.66 & 77.66 & 41.83 & 49.50 & 3.01 & 3.56 & 891.89 & 1055.34 \\
\hline \multicolumn{2}{|c|}{ Mean (Irr. In.) } & 65.44 & 76.49 & 43.22 & 50.66 & 3.11 & 3.64 & 981.23 & 1149.95 \\
\hline \multirow{3}{*}{$\begin{array}{l}\text { Mean } \\
\text { (Shading) }\end{array}$} & $0 \%$ & 65.91 & 78.87 & 45.49 & 52.95 & 3.27 & 3.80 & 1220.29 & 1418.76 \\
\hline & $30 \%$ & 68.87 & 80.08 & 46.25 & 53.45 & 3.33 & 3.84 & 1261.08 & 1457.32 \\
\hline & $60 \%$ & 69.99 & 80.91 & 43.70 & 52.58 & 3.14 & 3.77 & 1117.30 & 1347.48 \\
\hline \multirow{3}{*}{$\begin{array}{l}\text { L.S.D. at } \\
0.05\end{array}$} & Irr.In. & 4.09 & 6.90 & 2.81 & 4.65 & 0.19 & 0.32 & 75.96 & 128.88 \\
\hline & Sh. & 2.49 & 4.31 & 1.67 & 2.88 & 0.11 & 0.20 & 46.92 & 77.04 \\
\hline & Irr. In. $\times$ Sh. & 2.86 & 4.96 & 1.91 & 3.31 & 0.13 & 0.22 & 53.93 & 88.55 \\
\hline
\end{tabular}

while shading $(60 \%)$ gave the lowest number of leaves (43.70 and 52.58 leaves per plant), leaves dry weights (3.14 and $3.77 \mathrm{~g})$ and leaves area (1117.30 and 1347.48 $\mathrm{cm}^{2}$ ) in the first and second seasons, respectively.

Regarding the interaction between effect of irrigation intervals and shading treatments on the leaves characteristics, the data in Table (1) showed that the lowest mean values in the plant height (63.33 and 74.83 $\mathrm{cm})$, were obtained in plants irrigated at (28 days) and shading $(0 \%)$, while lowest leaves number were $(41.83$ and 49.50 leaves per plant), leaves dry weight were (3.01 and $3.56 \mathrm{~g})$ and leaves area were (891.89 and $\left.1055.34 \mathrm{~m}^{2}\right)$ in the first and second seasons, respectively, were obtained in plants irrigation intervals (28 days) and shading (60\%), On the other hand, the highest mean values in the plant height (71.83 and 83.00 $\mathrm{cm})$, were obtained when plants were irrigated at (7 days) intervals and shading $(60 \%)$, while leaves number were (47.50 and 54.83 leaves per plant), leaves dry weight were (3.42 and $3.95 \mathrm{~g}$ ) and leaves area were $\left(1518.11\right.$ and $\left.1754.98 \mathrm{~m}^{2}\right)$ were recorded in plants irrigation intervals (7 days) and shading (30\%), in the first and second seasons, respectively.

\section{Stem characteristics}

Data in Table (2) showed that increasing the irrigation intervals caused a significant reduction in the stem characteristics. The highest significant reduction was obtained from the biggest irrigation intervals (28 days) which gave stem diameter $(1.84$ and $2.32 \mathrm{~cm})$, caudex diameter $(47.72$ and $60.14 \mathrm{~cm})$, stem dry weight (25.65 and $29.99 \mathrm{~g}$ ) and caudex dry weight (34.22 and $40.00 \mathrm{~g}$ ) in the first and second seasons, respectively, compared with lowest irrigation intervals ( 7 days) which gave highest stem diameter were (2.06 and 2.54 $\mathrm{cm})$, caudex diameter were $(53.47$ and $65.88 \mathrm{~cm})$, stem dry weight were $(27.59$ and $31.99 \mathrm{~g})$ and caudex dry weight were ( 36.80 and $42.67 \mathrm{~g}$ ) in the first and second seasons, respectively. 
Table 2. Means of stem diameter $(\mathrm{cm})$, caudex diameter $(\mathrm{cm})$, stem dry weight $(\mathrm{g})$, and caudex dry weight $(\mathrm{g})$ of Beaucarnea recurvata plants as influenced by irrigation intervals (Irr. In.), shading (Sh.) and their interactions (Irr. In. × Sh.) in the two seasons of 2017 and 2018.

\begin{tabular}{|c|c|c|c|c|c|c|c|c|c|}
\hline \multicolumn{2}{|l|}{ Treatments } & \multicolumn{2}{|c|}{$\begin{array}{c}\text { Stem diameter } \\
(\mathrm{cm})\end{array}$} & \multicolumn{2}{|c|}{$\begin{array}{c}\text { Caudex diameter } \\
(\mathrm{cm})\end{array}$} & \multicolumn{2}{|c|}{$\begin{array}{c}\text { Stem dry weight } \\
\text { (g) }\end{array}$} & \multicolumn{2}{|c|}{$\begin{array}{c}\text { Caudex dry weigh } \\
\text { (g) }\end{array}$} \\
\hline $\begin{array}{l}\text { Irrigation } \\
\text { intervals } \\
\text { (day) }\end{array}$ & $\begin{array}{r}\text { Shading } \\
(\%)\end{array}$ & 2017 & 2018 & 2017 & 2018 & 2017 & 2018 & 2017 & 2018 \\
\hline \multirow{3}{*}{7 days } & $0 \%$ & 2.08 & 2.55 & 53.80 & 65.94 & 27.70 & 31.43 & 36.95 & 41.92 \\
\hline & $30 \%$ & 2.12 & 2.61 & 54.92 & 67.45 & 28.16 & 32.53 & 37.56 & 43.40 \\
\hline & $60 \%$ & 2.00 & 2.48 & 51.69 & 64.26 & 26.92 & 32.01 & 35.91 & 42.71 \\
\hline \multirow[t]{2}{*}{ Mean (Irr. In.) } & & 2.06 & 2.54 & 53.47 & 65.88 & 27.59 & 31.99 & 36.80 & 42.67 \\
\hline & $0 \%$ & 2.07 & 2.54 & 53.76 & 65.86 & 27.70 & 31.95 & 36.95 & 42.62 \\
\hline \multirow[t]{2}{*}{14 days } & $30 \%$ & 2.08 & 2.56 & 53.89 & 66.33 & 27.77 & 32.14 & 37.04 & 42.88 \\
\hline & $60 \%$ & 1.79 & 2.50 & 46.44 & 64.61 & 25.22 & 31.56 & 33.64 & 42.10 \\
\hline \multirow[t]{2}{*}{ Mean (Irr. In.) } & & 1.98 & 2.53 & 51.36 & 65.60 & 26.89 & 31.88 & 35.87 & 42.53 \\
\hline & $0 \%$ & 1.94 & 2.48 & 50.36 & 64.27 & 26.40 & 31.75 & 35.21 & 42.36 \\
\hline \multirow[t]{2}{*}{21 days } & $30 \%$ & 2.07 & 2.52 & 53.63 & 65.21 & 27.70 & 31.43 & 36.96 & 41.92 \\
\hline & $60 \%$ & 1.92 & 2.48 & 49.84 & 64.09 & 26.59 & 31.36 & 35.47 & 41.84 \\
\hline \multirow[t]{2}{*}{ Mean (Irr. In.) } & & 1.97 & 2.49 & 51.27 & 64.52 & 26.89 & 31.51 & 35.88 & 42.04 \\
\hline & $0 \%$ & 1.88 & 2.35 & 48.68 & 60.73 & 26.00 & 30.19 & 34.69 & 40.27 \\
\hline \multirow[t]{2}{*}{28 days } & $30 \%$ & 1.90 & 2.37 & 49.07 & 61.42 & 26.13 & 30.45 & 34.86 & 40.61 \\
\hline & $60 \%$ & 1.75 & 2.25 & 45.41 & 58.28 & 24.83 & 29.34 & 33.12 & 39.13 \\
\hline Mean (Irr. In.) & & 1.84 & 2.32 & 47.72 & 60.14 & 25.65 & 29.99 & 34.22 & 40.00 \\
\hline \multirow{3}{*}{$\begin{array}{l}\text { Mean } \\
\text { (Shading) }\end{array}$} & $0 \%$ & 1.99 & 2.48 & 51.65 & 64.20 & 26.95 & 31.33 & 35.95 & 41.79 \\
\hline & $30 \%$ & 2.04 & 2.51 & 52.87 & 65.10 & 27.44 & 31.63 & 36.60 & 42.20 \\
\hline & $60 \%$ & 1.86 & 2.42 & 48.34 & 62.81 & 25.89 & 31.06 & 34.53 & 41.44 \\
\hline \multirow{3}{*}{ L.S.D. at 0.05} & Irr. In. & 0.18 & 0.29 & 4.59 & 7.77 & 1.60 & 2.70 & 2.13 & 3.61 \\
\hline & Sh. & 0.11 & 0.18 & 2.85 & 4.86 & 0.97 & 1.69 & 1.30 & 2.25 \\
\hline & Irr. In. $\times$ Sh. & 0.12 & 0.21 & 3.27 & 1.88 & 1.11 & 1.94 & 1.49 & 2.59 \\
\hline
\end{tabular}

In contrast to the effect of irrigation intervals treatments, shading treatments improved growth of Beaucarnea recurvata plants. The lowest significant result was obtained from $(30 \%)$ shading which gave the highest stem diameter $(2.04$ and $2.51 \mathrm{~cm})$, caudex diameter $(52.87$ and $65.10 \mathrm{~cm})$, stem dry weight $(27.44$ and $31.63 \mathrm{~g}$ ) and caudex dry weight (36.60 and $42.20 \mathrm{~g}$ ) in the first and second seasons, respectively, compared with control value which gave the lowest stem diameter (1.99 and $2.48 \mathrm{~cm}$ ), caudex diameter $(51.65$ and 64.20 $\mathrm{cm}$ ), stem dry weight (26.95 and $31.33 \mathrm{~g}$ ) and caudex dry weight ( 35.95 and $41.79 \mathrm{~g}$ ) in the first and second seasons, respectively.

Regarding the interaction between effect of irrigation intervals and shading treatments on stem characteristics, the data in Table (2) showed that the highest mean values in the stem diameter were (2.12 and $2.61 \mathrm{~cm})$, caudex diameter were $(54.92$ and $67.45 \mathrm{~cm})$, stem dry weight were (28.16 and $32.53 \mathrm{~g})$ and caudex dry weight were (37.56 and $43.40 \mathrm{~g})$ in the first and second seasons, respectively, were obtained in plants when irrigation intervals were (7 days) and shading (30\%), while the lowest mean values in the stem diameter were $(1.75$ and $2.25 \mathrm{~cm})$, caudex diameter were $(45.41$ and $58.28 \mathrm{~cm})$, stem dry weight were $(24.83$ and $29.34 \mathrm{~g}$ ) and caudex dry weight were (33.12 and $39.13 \mathrm{~g})$ were obtained in plants irrigation intervals $(28$ days) and shading (60\%) in the first and second seasons, respectively.

\section{Root characteristics}

Data presented in Table (3) showed that irrigation intervals significantly decreased the root characteristics of Beaucarnea recurvata plants. Plants irrigated at (7 days) intervals had the highest mean root length (17.81 and $20.65 \mathrm{~cm}$ ) and root dry weight (13.71 and $15.89 \mathrm{~g})$ in the first and second seasons, respectively, 
Table 3. Means of root length $(\mathrm{cm})$ and root dry weight $(\mathrm{g})$ of Beaucarnea recurvata plants as influenced by irrigation intervals (Irr. In.), shading (Sh.) and their interactions (Irr. In. $\times$ Sh.) in the two seasons of 2017 and 2018.

\begin{tabular}{|c|c|c|c|c|c|}
\hline \multirow{2}{*}{$\begin{array}{l}\text { Treatments } \\
\begin{array}{l}\text { Irrigation intervals } \\
\text { (day) }\end{array}\end{array}$} & \multirow[b]{2}{*}{$\begin{array}{l}\text { Shading } \\
(\%)\end{array}$} & \multicolumn{2}{|c|}{$\begin{array}{l}\text { Root length } \\
(\mathrm{cm})\end{array}$} & \multicolumn{2}{|c|}{$\begin{array}{c}\text { Root dry weight } \\
\text { (g) }\end{array}$} \\
\hline & & 2017 & 2018 & 2017 & 2018 \\
\hline \multirow{3}{*}{7 days } & $0 \%$ & 17.88 & 20.30 & 13.77 & 15.61 \\
\hline & $30 \%$ & 18.18 & 21.00 & 13.99 & 16.17 \\
\hline & $60 \%$ & 17.37 & 20.66 & 13.38 & 15.91 \\
\hline \multirow{2}{*}{ Mean (Irrg. Inte.) } & & 17.81 & 20.65 & 13.71 & 15.89 \\
\hline & $0 \%$ & 17.88 & 20.62 & 13.76 & 15.87 \\
\hline \multirow[t]{2}{*}{14 days } & $30 \%$ & 17.92 & 20.75 & 13.80 & 15.97 \\
\hline & $60 \%$ & 16.28 & 20.38 & 12.53 & 15.68 \\
\hline \multirow[t]{2}{*}{ Mean (Irrg. Inte.) } & & 17.36 & 20.58 & 13.36 & 15.84 \\
\hline & $0 \%$ & 17.04 & 20.5 & 13.11 & 15.78 \\
\hline \multirow[t]{2}{*}{21 days } & $30 \%$ & 17.88 & 20.28 & 13.77 & 15.61 \\
\hline & $60 \%$ & 17.16 & 20.24 & 13.21 & 15.58 \\
\hline \multirow[t]{2}{*}{ Mean (Irrg. Inte.) } & & 17.36 & 20.34 & 13.36 & 15.65 \\
\hline & $0 \%$ & 16.78 & 19.49 & 12.92 & 15.00 \\
\hline \multirow[t]{2}{*}{28 days } & $30 \%$ & 16.87 & 19.65 & 12.99 & 15.13 \\
\hline & $60 \%$ & 16.02 & 18.94 & 12.33 & 14.58 \\
\hline \multirow[t]{2}{*}{ Mean (Irrg. Inte.) } & & 16.55 & 19.36 & 12.74 & 14.90 \\
\hline & $0 \%$ & 17.39 & 20.22 & 13.39 & 15.56 \\
\hline \multirow[t]{3}{*}{ Mean (Shading) } & $30 \%$ & 17.71 & 20.42 & 13.63 & 15.72 \\
\hline & $60 \%$ & 16.70 & 20.05 & 12.86 & 15.43 \\
\hline & Irr. In. & 1.03 & 1.74 & 0.79 & 1.34 \\
\hline \multirow[t]{2}{*}{ L.S.D. at 0.05} & Sh. & 0.63 & 1.09 & 0.48 & 0.84 \\
\hline & Irr. In. $\times$ Sh. & 0.72 & 1.25 & 0.55 & 0.96 \\
\hline
\end{tabular}

while the lowest root length of $(16.55$ and $19.36 \mathrm{~cm})$ and root dry weight of (12.74 and $14.90 \mathrm{~g})$ in the first and second seasons, respectively, were obtained from plants treated with irrigation interval (28 days).

Data in Table (3) indicated that the different shading treatments had a significant effect on the root characteristics. Plants shaded with $(30 \%)$ gave the highest mean root length $(17.71$ and $20.42 \mathrm{~cm})$ and root dry weight (13.63 and $15.72 \mathrm{~g})$ in the first and second seasons, respectively, compared with the plants shaded with $(60 \%)$ which gave the lowest mean root length of $(16.70$ and $20.05 \mathrm{~cm})$ and root dry weight of (12.86 and $15.43 \mathrm{~g}$ ) in the first and second seasons, respectively.

Regarding the interaction between the effect of irrigation intervals and different shading treatments on the root characteristics, data in Table (3) showed that the highest mean values in the root length (18.18 and 21.00 $\mathrm{cm})$ and root dry weight (13.99 and $16.17 \mathrm{~g}$ ) in the first and second seasons, respectively, were obtained in plants following using the irrigation interval ( 7 days) and shading (30\%), while the lowest mean values in the root length of $(16.02$ and $18.94 \mathrm{~cm})$ and root dry weight of (12.33 and $14.58 \mathrm{~g})$ in the first and second seasons, respectively, were obtained in plants which received irrigation interval at (28 days) and shading at (60\%).

\section{Chemical constituents}

\subsection{Total chlorophyll (SPAD) and carbohydrate contents $(\%)$}

The results presented in Table (4) showed that the highest content of total chlorophyll were (36.99 and 42.89 SPAD) and carbohydrate contents (5.23 and 6.07 in the first and second seasons, respectively, were obtained at irrigation intervals of (7 days). Increasing irrigation intervals to (28 days) resulted in steady significant reductions in the total chlorophyll contents (34.39 and 40.20 SPAD) and carbohydrate contents (4.87 and $5.69 \%)$ in the first and second seasons, respectively. 
Moreover, Table (4) illustrated that the different shading treatments had a clear positive effect on the total chlorophyll and carbohydrate contents. Highest mean values of total chlorophyll (36.82 and 42.53 SPAD) were obtained at $(60 \%)$ shading and carbohydrate contents (5.20 and $6.00 \%)$ were obtained at $(30 \%)$ shading in the first and second seasons, respectively.

Data in Table (4) clearly showed that a significant interaction was detected between the effects of irrigation intervals and different shading treatments on total chlorophyll and carbohydrate contents in Beaucarnea recurvata plants. The highest total chlorophyll contents of (37.76 and 43.63 SPAD) were obtained in plants irrigated at (7 days) intervals and $(60 \%)$ shading and carbohydrate contents of $(5.34$ and $6.18 \%)$ were obtained at irrigation interval of (7 days) and shading of $(30 \%)$ in the first and second seasons, respectively. On the other hand, the lowest chlorophyll contents (33.30 and 39.35 SPAD) were obtained in plants irrigated at (28 days) intervals and $(0 \%)$ shading and carbohydrate contents of (4.71 and $5.57 \%)$ were obtained in plants irrigated at (28 days) interval and (60\%) shading in the first and second seasons, respectively.

\subsection{Proline content $(\mathrm{mg} / \mathrm{g} \mathrm{D} . \mathrm{W})$ and relative water content (\%)}

The results presented in Table (4) showed that the lowest mean of proline content $(1.28$ and $1.32 \mathrm{mg} / \mathrm{g}$ D.W) and relative water content (49.65 and $46.38 \%$ ) in the first and second seasons, respectively, were obtained in plants irrigated at (7 days) intervals. Increasing irrigation intervals to (28 days) resulted in steady significant increase in the proline content $(2.45$ and 2.41 mg/g D.W) and relative water content (74.46 and 70.40 $\%)$ in the first and second seasons, respectively.

Moreover, Table (4) illustrated that the different shading treatments had a clear positive effect on the proline content and relative water content. Highest mean values of proline content (1.95 and $1.98 \mathrm{mg} / \mathrm{g} \mathrm{D.W})$ were obtained at $(0 \%)$ shading, while the relative water content $(63.87$ and $60.62 \%)$ were obtained at $(60 \%)$ shading in the first and second seasons, respectively.

Table 4. Means of leaves chlorophyll (SPAD), carbohydrate $(\%)$, proline $(\mathrm{mg} / \mathrm{g} \mathrm{D.W})$ and relative water content (\%) of Beaucarnea recurvata plants as influenced by irrigation intervals (Irr. In.), shading (Sh.) and their interactions (Irr. In. $\times$ Sh.) in the two seasons of 2017 and 2018.

\begin{tabular}{|c|c|c|c|c|c|c|c|c|c|}
\hline \multirow{2}{*}{$\begin{array}{l}\text { Treatments } \\
\text { Irrigation intervals } \\
\text { (day) }\end{array}$} & \multirow[b]{2}{*}{$\begin{array}{l}\text { Shading } \\
(\%)\end{array}$} & \multicolumn{2}{|c|}{$\begin{array}{l}\text { Chlorophyll } \\
\text { content } \\
\text { (SPAD) }\end{array}$} & \multicolumn{2}{|c|}{$\begin{array}{c}\text { Carbohydrates } \\
\text { content } \\
(\%)\end{array}$} & \multicolumn{2}{|c|}{$\begin{array}{c}\text { Proline } \\
\text { content } \\
(\mathrm{mg} / \mathrm{g} \mathrm{D} . \mathrm{W})\end{array}$} & \multicolumn{2}{|c|}{$\begin{array}{c}\text { Relative water } \\
\text { content } \\
(\%)\end{array}$} \\
\hline & & 2017 & 2018 & 2017 & 2018 & 2017 & 2018 & 2017 & 2018 \\
\hline \multirow{3}{*}{7 days } & $0 \%$ & 36.08 & 42.13 & 5.26 & 6.08 & 1.34 & 1.37 & 43.63 & 42.03 \\
\hline & $30 \%$ & 37.15 & 42.93 & 5.34 & 6.18 & 1.31 & 1.35 & 50.87 & 47.34 \\
\hline & $60 \%$ & 37.76 & 43.63 & 5.11 & 5.97 & 1.20 & 1.25 & 54.45 & 49.79 \\
\hline \multirow[t]{2}{*}{ Mean (Irr. In.) } & & 36.99 & 42.89 & 5.23 & 6.07 & 1.28 & 1.32 & 49.65 & 46.38 \\
\hline & $0 \%$ & 33.81 & 42.30 & 5.26 & 6.07 & 1.80 & 1.84 & 55.67 & 52.70 \\
\hline \multirow[t]{2}{*}{14 days } & $30 \%$ & 37.15 & 42.85 & 5.27 & 6.10 & 1.76 & 1.79 & 57.87 & 55.07 \\
\hline & $60 \%$ & 37.35 & 43.11 & 4.79 & 5.99 & 1.76 & 1.79 & 58.44 & 56.97 \\
\hline \multirow[t]{2}{*}{ Mean (Irr. In.) } & & 36.10 & 42.75 & 5.10 & 6.05 & 1.77 & 1.80 & 57.32 & 54.91 \\
\hline & $0 \%$ & 35.36 & 42.05 & 5.05 & 6.03 & 2.21 & 2.27 & 63.70 & 61.39 \\
\hline \multirow{2}{*}{21 days } & $30 \%$ & 35.63 & 42.15 & 5.26 & 5.97 & 2.17 & 2.22 & 65.75 & 62.78 \\
\hline & $60 \%$ & 37.15 & 42.58 & 5.01 & 5.95 & 2.19 & 2.24 & 66.38 & 64.23 \\
\hline \multirow[t]{2}{*}{ Mean (Irr. In.) } & & 36.04 & 42.26 & 5.10 & 5.98 & 2.19 & 2.24 & 65.27 & 62.80 \\
\hline & $0 \%$ & 33.30 & 39.35 & 4.94 & 5.73 & 2.46 & 2.44 & 73.07 & 69.33 \\
\hline \multirow[t]{2}{*}{28 days } & $30 \%$ & 34.85 & 40.46 & 4.96 & 5.78 & 2.44 & 2.41 & 74.07 & 70.38 \\
\hline & $60 \%$ & 35.03 & 40.81 & 4.71 & 5.57 & 2.45 & 2.40 & 76.24 & 71.50 \\
\hline \multirow[t]{2}{*}{ Mean (Irr. In.) } & & 34.39 & 40.20 & 4.87 & 5.69 & 2.45 & 2.41 & 74.46 & 70.40 \\
\hline & $0 \%$ & 34.63 & 41.45 & 5.12 & 5.97 & 1.95 & 1.98 & 59.01 & 56.36 \\
\hline \multirow[t]{3}{*}{ Mean (Shading) } & $30 \%$ & 36.19 & 42.09 & 5.20 & 6.00 & 1.92 & 1.94 & 62.14 & 58.89 \\
\hline & $60 \%$ & 36.82 & 42.53 & 4.90 & 5.87 & 1.90 & 1.92 & 63.87 & 60.62 \\
\hline & Irr. In. & 2.16 & 3.63 & 0.30 & 0.51 & 0.05 & 0.04 & 9.64 & 7.77 \\
\hline \multirow[t]{2}{*}{ L.S.D. at 0.05} & Sh. & 1.33 & 2.26 & 0.18 & 0.32 & 0.02 & 0.01 & 0.97 & 0.96 \\
\hline & Irr. In. $\times$ Sh. & 1.52 & 2.60 & 0.21 & 0.36 & 0.02 & 0.02 & 1.12 & 1.10 \\
\hline
\end{tabular}


Data in Table (4) clearly showed that a significant interaction was detected between the effects of irrigation intervals and different shading treatments on proline and relative water content in Beaucarnea recurvata plants. The highest proline content ( 2.46 and $2.44 \mathrm{mg} / \mathrm{g} \mathrm{D} . \mathrm{W})$ was obtained in plants irrigated at (28 days) intervals and $(0 \%)$ shading, while the relative water content of (76.24 and $71.50 \%$ ) was obtained in plants when irrigation intervals of (28 days) and shading at (60\%) were used in the first and second seasons, respectively. On the other hand, the lowest proline content of $(1.20$ and $1.25 \mathrm{mg} / \mathrm{g} \mathrm{D.W)} \mathrm{was} \mathrm{obtained} \mathrm{in} \mathrm{plants} \mathrm{applied}$ with irrigation intervals at ( 7 days) and shading at $(60 \%)$, while the relative water content of (43.63 and $42.03 \%)$ was obtained in plants treated at (7 days) intervals and shading at $(0 \%)$ in the first and second seasons, respectively.

\section{Nitrogen, Phosphorus and Potassium contents in leaves $(\%)$}

Table (5) showed that, the percentages of nitrogen, phosphorus and potassium contents in dried leaves of Beaucarnea recurvata plants have decreased steadily with increasing the irrigation intervals. The highest percentages of nitrogen ( 2.16 and $2.51 \%$ ), phosphorus $(0.216$ and $0.252 \%)$ and potassium $(2.35$ and $2.70 \%)$ in the first and second seasons, respectively, were found in plants at irrigation interval of (7 days), whereas the lowest mean values of nitrogen (2.01 and $2.35 \%)$, phosphorus $(0.201$ and $0.236 \%)$ and potassium (2.21 and $2.54 \%$ ) in the first and second seasons, respectively, were found in plants that were irrigated with irrigation interval (28 days).

Table (5) showed that shading treatments had a clear positive effect on the percentage of nitrogen, phosphorus and potassium content in plants. Plants shaded at $(30 \%)$ had the highest nitrogen content in their leaves (2.15 and $2.48 \%)$,

Table 5. Means of Nitrogen, Phosphorus and Potassium contents in leaves (\%) of Beaucarnea recurvata plants as influenced by irrigation intervals (Irr. In.), shading (Sh.) and their interactions (Irr. In. $\times$ Sh.) in the two seasons of 2017 and 2018.

\begin{tabular}{|c|c|c|c|c|c|c|c|}
\hline \multirow{2}{*}{$\begin{array}{l}\text { Treatments } \\
\begin{array}{l}\text { Irrigation intervals } \\
\text { (day) }\end{array} \\
\end{array}$} & \multirow[b]{2}{*}{$\begin{array}{l}\text { Shading } \\
(\%)\end{array}$} & \multicolumn{2}{|c|}{$\begin{array}{c}\text { Nitrogen content in } \\
\text { leaves } \\
(\%)\end{array}$} & \multicolumn{2}{|c|}{$\begin{array}{c}\text { Phosphorus content in } \\
\text { leaves } \\
(\%)\end{array}$} & \multicolumn{2}{|c|}{$\begin{array}{c}\text { Potassium content } \\
\text { in leaves } \\
(\%)\end{array}$} \\
\hline & & 2017 & 2018 & 2017 & 2018 & 2017 & 2018 \\
\hline \multirow{3}{*}{7 days } & $0 \%$ & 2.17 & 2.52 & 0.217 & 0.252 & 2.36 & 2.71 \\
\hline & $30 \%$ & 2.21 & 2.55 & 0.222 & 0.256 & 2.41 & 2.75 \\
\hline & $60 \%$ & 2.11 & 2.47 & 0.211 & 0.248 & 2.30 & 2.66 \\
\hline \multirow{2}{*}{ Mean (Irr. In.) } & & 2.16 & 2.51 & 0.216 & 0.252 & 2.35 & 2.70 \\
\hline & $0 \%$ & 2.17 & 2.51 & 0.218 & 0.251 & 2.36 & 2.70 \\
\hline \multirow[t]{2}{*}{14 days } & $30 \%$ & 2.18 & 2.52 & 0.219 & 0.254 & 2.37 & 2.72 \\
\hline & $60 \%$ & 1.98 & 2.48 & 0.198 & 0.248 & 2.17 & 2.67 \\
\hline \multirow[t]{2}{*}{ Mean (Irr. In.) } & & 2.11 & 2.50 & 0.211 & 0.251 & 2.30 & 2.69 \\
\hline & $0 \%$ & 2.09 & 2.49 & 0.209 & 0.249 & 2.28 & 2.68 \\
\hline \multirow[t]{2}{*}{21 days } & $30 \%$ & 2.17 & 2.47 & 0.219 & 0.248 & 2.36 & 2.66 \\
\hline & $60 \%$ & 2.07 & 2.46 & 0.207 & 0.246 & 2.27 & 2.66 \\
\hline \multirow[t]{2}{*}{ Mean (Irr. In.) } & & 2.11 & 2.47 & 0.211 & 0.247 & 2.30 & 2.66 \\
\hline & $0 \%$ & 2.04 & 2.37 & 0.204 & 0.237 & 2.24 & 2.56 \\
\hline \multirow[t]{2}{*}{28 days } & $30 \%$ & 2.05 & 2.39 & 0.205 & 0.239 & 2.25 & 2.58 \\
\hline & $60 \%$ & 1.95 & 2.30 & 0.196 & 0.232 & 2.14 & 2.49 \\
\hline \multirow[t]{2}{*}{ Mean (Irr. In.) } & & 2.01 & 2.35 & 0.201 & 0.236 & 2.21 & 2.54 \\
\hline & $0 \%$ & 2.11 & 2.47 & 0.212 & 0.247 & 2.31 & 2.66 \\
\hline \multirow[t]{3}{*}{ Mean (Shading) } & $30 \%$ & 2.15 & 2.48 & 0.216 & 0.249 & 2.34 & 2.67 \\
\hline & $60 \%$ & 2.02 & 2.42 & 0.203 & 0.243 & 2.22 & 2.62 \\
\hline & Irr. In. & 0.12 & 0.21 & 0.012 & 0.021 & 0.12 & 0.20 \\
\hline \multirow[t]{2}{*}{ L.S.D. at 0.05} & Sh. & 0.07 & 0.13 & 0.007 & 0.013 & 0.07 & 0.13 \\
\hline & Irr. In. $\times$ Sh. & 0.08 & 0.15 & 0.009 & 0.015 & 0.08 & 0.15 \\
\hline
\end{tabular}


phosphorus (0.216 and $0.249 \%)$ and potassium (2.34 and $2.67 \%$ ) in the first and second seasons, respectively, compared with the plants shaded with (60\%) which had the lowest nitrogen content in their leaves (2.02 and $2.42 \%$ ), phosphorus $(0.203$ and 0.243 $\%)$ and potassium (2.22 and $2.62 \%$ ) in the first and second seasons, respectively.

Concerning the interaction effect between irrigation intervals and shading treatments on the content of nitrogen, phosphorus and potassium in dried leaves of Beaucarnea recurvata plants, Table (5) showed that the highest percentages of nitrogen were (2.21 and $2.55 \%$ ), phosphorus were $(0.222$ and $0.256 \%)$ and potassium were (2.41 and $2.75 \%)$, formed by plants irrigated with irrigation intervals (7 days) and shading (30\%). On the other hand, the lowest percentages of nitrogen were (1.95 and $2.30 \%)$, phosphorus were $(0.196$ and 0.232 $\%)$ and potassium were (2.14 and $2.49 \%$ ), formed by plants irrigated with irrigation intervals (28 days) and shading $(60 \%)$ treatments. in the first and second seasons, respectively.

\section{DISCUSSION}

Baher et al. (2002) reported that uttermost soil water stress reduced plant height, total fresh and dry weight of Satureja hortensis. While, Leithy et al. (2006) found that, exposing rosemary plants to water stress led down to a decrease in growth parameters at different cuts. ElNaim and Ahmed (2010) found that frequent irrigation intervals (7 days) improved vegetative growth, i.e. plant height, stem diameter, number of leaves per plant, leaf area index and shoot dry weight of sunflower. Bettaieb et al. (2012) found that cumin plant treated with moderate water deficit (MWD) improved the quantity of umbels per plant likewise the number of umbellets per umble and also the seed yield, compared to the management plant, however it reduced underneath severe water deficit (SWD). El-Mekawy (2013) on herbaceous plant Achillea santolina L. showed that irrigation each seven days, extremely improved the number of branches per plant, plant height, fresh and dry weight of herb/plant, fresh and dry weight of roots/plant compared to irrigation each fourteen and twenty one days. Silva et al. (2010) on Aloe vera, Al-Kayssi et al. (2011) on black cumin, Rebey et al. (2012) on cumin plant, Sidika et al. (2012) on purple basil, Lal et al. (2013) on lemon grass and Vazin (2013) on cumin plant found that providing the plants with appropriate water amounts resulted in higher growth and yield than those mature underneath drier conditions. The previous results are in line with the results obtained in this experiment.
The results of the current research go in harmony with those of Farooq et al. (2009) rumored that drought stress reduces plant growth by numerous physiological and organic chemistry processes, like photosynthesis, respiration, translocation, ion uptake, carbohydrates, nutrient metabolism and growth promoters. El-Azim et al. (2009) on Peganum harmala L. mentioned that prolonging the irrigation interval from ten to thirty days, led to that the share of crude protein, total ash, potassium and total flavonoids in plant tissues were minimized (Ekren et al., 2012). Exposing rosemary plant to water stress led to a decrease in $\mathrm{N}, \mathrm{P}, \mathrm{K}$, and protein contents. Amirjani (2013) explicit that seedlings of Catharanthus roseus subjected to four completely different water regimes. The primary irrigation was each one week, the second treatment was each fortnight, the third treatment was irrigation each 3 weeks, whereas the control plants were irrigated every day. The photosynthetic activity and transpiration rate considerably minimized with increasing drought level. Total protein decreased to seventy seven and total pigment decreased by twenty seventh.

The best treatment was with the irrigation every one week. The trend of results united with those obtained by Leithy et al. 2006 on rosemary plant, Bettaieb et al. 2012 on cumin plant and El-Mekawy (2013) on herb genus Achillea santolina L. and El-Tahir et al. (2011) according that, this could result to very important roles of water system at adequate quantity of various physiological processes like photosynthesis, respiration, transpiration, translocation, catalyst reaction and cell prolixity happens at the same time. Moreover, increasing levels of water stress scale back growth and yield because of reduction in photosynthesis by low carbon dioxide convenience because of reduced stomata.

The present results are in harmony with those of ElMekawy (2012) mentioned that the result of irrigation intervals on carbohydrates percentage of black cumin was reduced considerably by decreasing the soil wetness content as a results of increasing the irrigation intervals from two up to six days intervals. Rabia et al. (2013) found that the carbohydrates percentage of genus Echinacea purpurea L. considerably ablated as a response to the decrease in irrigation water amount and reached their minimum price beneath very cheap irrigation.

Soil water content inflated with inflated shade levels altogether cultivars. Possibly, shading reduced evaporative change demand and caused reduced transpiration, leading to faded soil water uptake by bell pepper (Moller et al., 2004 and Kittas et al., 2009). In 
unmulched soil, shading might conjointly scale back soil evaporation. A half-hour black shading web reduced radiation, wind speed, and water necessities and inflated irrigation water use potency in bell pepper (Moller and Assouline, 2007). Similarly, in greenhouse-grown tomato (Solanum Lycopersicon L.), crop water use faded and water use potency inflated with shade level (Gent, 2008). Shading conjointly reduces water necessities and will increase irrigation water use potency (Moller and Assouline, 2007).

Our results are in agreement with the previous studies, which indicated that the moderate shade levels (30-40\%) failed to decrease average of leaf chlorophyll content considerably, that was favourable for bell pepper plant growth (Shahak et al., 2008 and Díaz-Pérez, 2013).

\section{REFERENCES}

Al-Kayssi A.W., R.M. Shihab and S.H. Mustafa. 2011. Impact of Soil Water Stress on Nigellone oil content of black cumin seeds grown in calcareous-gypsifereous soils. Agric Water Manag 100: 46-57.

Allen O.M. 1959. Experimental in soil Bacteriology. Burgess Publishing Co. Minneapolis USA. p. $83-85$.

Amirjani M.R. 2013. Effects of drought stress on the alkaloid contents and growth parameters of Catharanthus roseus. ARPN J Agric Bio Sci 8 (11): 745-750.

Baher Z.F., M. Muza, M. Ghorbanli and M.B. Rezaii. 2002. The influence of water stress on plant height, herbal and essential oil yield an decomposition in Satureja hortensis L. Flav Frag 6: 127-32.

Barrs D. 1968. Determination of water deficits in plant tissues. Vol.1 pp. 235 - 368. In: water deficits and plant growth. T.T. Kozlowski (ed.). Academic Press, London.

Bates L.S., R.P. Waldern and L. D. Teare. 1973. Rapid determination of free proline under water stress studies. Plant and Soil, 39: 205-207.

Bettaieb I., S. Knioua, I. Hamrouni, F. Limam and B. Marzouk. 2011. Waterdeficit impact on fatty acid and essential oil composition and antioxidant activities of cumin (Cuminum cyminum L.) aerial parts. J Agric Food Chem 59: 328-334.

Bettaieb I.R., I. Jabri-uroul, I. Hamrouni-Sellami, S. Bourgou, F. Limam and B. Murzouk. 2012. Effect of drought on the biochemical compositon and antioxidant activities of cumin (Cuminum cyminum L.) Seeds. Ind Crop Prod 36 (1): 238-245.

Bourgou S., I. Bettaieb, M. Saidani and B. Marzouk. 2011. Fatty acids, essential oil and phenolics modifications of black cumin fruit under $\mathrm{NaCl}$ stress conditions. J Agric Food Chem 59: 328-3434.

Boyhan G., J. Di'az-Pe'rez, C. Riner, R. Hill, and D. Thigpen. 2008. Evaluation of bell pepper and tomato varieties with and without shade. HortScience 43:1256.
Castellano S., G.S. Mugnozza, G. Russo, D. Briassoulis, A. Mistriotis, S. Hemming and D. Waaijenberg. 2008. Plastics net in agriculture: A general review of types and applications. Appl. Eng. Agr. 24:799-808.

Champman H. D. and P.F. Pratt. 1961. Method of Analysis of Soil, Plants and Water. Univ. of California p.61.

Diaz-Pérez J.C. 2013. Bell pepper (Capsicum annuum L.) crop as affected by shade level:microenvironment, plant growth, leaf gas exchange, and leaf mineral nutrient concentration. HortScience. 48:175-182.

Dubios M., Gilles K., Hamlton J., Rebers P. and F. Smith. 1956. Colourimetric method for determination of sugars and related substances. Analytical Chemistry, 28(3): 350356.

Ekren S., C. Sonmez, E. Ozcakal, Y.S.K. Kurttas, E. Bayram and H. Gurgulu. 2012. The effect of different irrigation water levels on yield and quality characteristics of purple basil (Ocimum basilicum L.). Agric Water Man 109, 155161.

El-Azim W.M.A., S.T. Ahmed and N.H. Mohamed. 2009. Effect of water and salt stress on the growth and chemical composition of Peganum harmala L. under Ras Sudr Con 60. (4): 433-442.

El-Mekawy M.A.M. 2012. Growth and yield of Nigella sativa L. plant influenced by sowing date and irrigation treatments. Amer-Eur J. Agric Environ Sci 12 (4): 499505.

El-Mekawy M.A.M. 2013. Response of Achillea santolina L. to fertilizers under different Irrigation intervals. Asi J Crop Sci 5: 338-359.

El-Naim A.M. and F. Ahmed. 2010. Effect of Irrigation Intervals and Inter-row spacing on the vegetative growth characteristics on sunflower (Helianthus annuus L.) hybrids in shombat soil. J. App. Res. 6 (9): 1446-1451.

El-Tahir B., A. El-Hawary and S.O. Yagaub. 2011. Effect of different irrigation intervals on wheat (Triticum aestivum) in semiarid regions of Sudan. J Sci Tech 12 (3): 75.

Farooq M., A. Wahid and N. Kobayashi. 2009. Plant drought stress: effects, mechanisms and management. Agron Sustain Dev 29 (1): 185-212.

Flevas J., H. Medrano. 2002. Drought-inhibition of photosynthesis in plants: stomatal and non stomatal limitation revisited. Ann Bot 89: 183-9.

Gent M.P.N. 2008. Density and duration of shade affect water and nutrient use in greenhouse tomato. J. Amer. Soc. Hort. Sci. 133:619-627.

Ilic, Z.S., L. Milenkovic, L. Stanojevic, D. Cvetkovic, and E. Fallik. 2012. Effects of the modification of light intensity by color shade nets on yield and quality of tomato fruits. Sci. Hort. 139:90-95.

Israelsen O. and V. Hansen .1962. Irrigation, Principles and Practices. John Wiley and Sons, Inc. New York.

Jackson M. L. 1958. Soil Chemical Analysis. Prentice Hall Inc. Englwood, Cliffs, NJ. USA. 
Kafi M., M.M. Damghan. 2001. Mechanisms of Environmental Stress Resistance in plants Publicaton Ferdowsi University, Mashhad.

Kittas C., N. Katsoulas, N. Rigakis, T. Bartzanas, and E. Kitta. 2012. Effects on microclimate, crop production and quality of a tomato crop grown under shade nets. J. Hort. Sci. Biotechnol. 87:7-12.

Kittas, C., N. Rigakis, N. Katsoulas, and T. Bartzanas. 2009. Influence of shading screens on microclimate, growth and productivity of tomato. Acta Hort. 807:97-102.

Koller H. R. 1972. Leaf area, leaf weight relationship in the soybean canopy. Crop Sci., 12: 180-183.

Lal K., R.K. Yadav, R. Kaur, D.S. Bundela, M.I. Khan. 2013. Productivity, essential oil yield and heavy metal accumulation in lemon grass (Cymbopogon flexuosus) under varied was water-ground water irrigation regimes. Ind Crop Prod 45: 270-278.

Laribi B., I. Bettaieb, K. Kouki, A. Sahli, A. Mougou, B. Marzouk. 2009. Water deficit effect on caraway (Carum carvi L.) growth, essential oil and fatty acid composition. Ind Crop Prod 31: 34-42.

Leithy S., T.A. El-Meseiry and E.F. Abdallah. 2006. Effect of/biofertilizer, cell stabilizer and irrigation regime on rosemary herbage oil yield and quality. J App Sci Res 2 (10): 773-779.

Moller M. and S. Assouline. 2007. Effects of a shading screen on microclimate and crop water requirements. Irrig. Sci. 25:171-81.

Moller M., J. Tanny, Y. Li, and S.T. Cohen. 2004. Measuring and predicting evapotranspiration in an insect-proof screenhouse. Agr. For. Meteorol. 127:35-51.

Rabia M.M. Yousef, Soha E. Khalil and Nadia A.M. El-Said. 2013. Response of Echinacea purpurea L. To irrigation water regime and biofertilization in sandy soils. World App Sci J 26 (6): 771-782.

Randhawa G.S., B.S. Gill and S.P. Raychanudhuri. 1992. Optimizing agronomic requirements of anise (Pimpinella anisum L. in the Punjab. Rescent Advances in Medicinal, Aromatic and Spice Crops. Vol 2. International Conference, 28-31 January 1989, New Delhi, India.
Rebey I.B., I. Jabri-Karoui, I. Hamrouni-Sellami, S. Bourgou, F. Limam, B. Marzou. 2012. Effect of drought on the biochemical composition and antioxidant activities of cumin (Cuminum cyminum L.) seeds. Ind Crop Prod 36: 238-245.

Ritchie J.J. 1974. Atmospheric and soil water influences on the plant water balance. Agric. Meth., 14, 1993 - 1998.

Rivera-Lugo M. and E. Solano .2012. Flora del Valle de Tehuacán- Cuicatlán, fasc. 99, Nolinaceae Nakai. Instituto de Biología, Universidad Nacional Autónoma de México.

Rylski I. and M. Spigelman. 1986. Effect of shading on plant development, yield and fruit quality of sweet pepper grown under onditions of high temperature and radiation. Sci. Hort. 29:31-35.

SAS Institute. 2002. SAS User Guide and Program 20 Version 9.0.38. Cary, North Carolina, USA.

Shahak Y., E. Gal, Y. Offir, D. Ben-Yakir. 2008. Photoselective shade netting integrated withgreenhouse technologies for improved performance of vegetable and ornamental crops. Acta Horticulturae, 797: 75-80.

Sidika E., C. Sonmez, E. Ozcakal, Y.S.K. Kurttas, E. Bayram and H. Gurgulu. 2012. The effect of different irrigation water levels on yield and quality characteristics on purple basil (Ocimum basilicum L.) Agric Water Manag 109: 155-161.

Silva H., S. Sagardia, O. Seguel, C. Torre, N. Tapia, Franck and L. Cardemi. 2010. Effect of water availability on growth and water use efficiency for biomass and production in Aloe vera (Aloe barbadensis M.). Ind. Crops Prod 31: 20-27.

Singh-Sangwan N., A.H.A. Farrooqi, F. Shabih and R.S. Sangwan. 2001. Resultation of essential oil production in plants. Plant Growth Reg 34: 3-21.

Snedecor G. W. and W. Cochran. 1989. Statistical Methods, $8^{\text {th }}$ ed. Edition, Iowa State University Press.

Vazin R. 2013. Water stress effects on cumin (Cuminum cyminum L.) yield and oil essential components. Sci Hort 151: 135-141.

Yadava U. 1986. A rapid and nondestructive method to determine chlorophyll in intact leaves. Hort. Sci., 21(6): 1449-1450. 


\section{الملخص العربي}

\section{تأثير فترات الرى والتظليل على جودة نمو نباتات الزلوعة}

$$
\text { نادر أحمد الثنهورى، منى عبد الحميد سرور }
$$

يتعلق بالتفاعل بين تأثنير فترات الري ومعالجات التظليل المختلفة على النمو الخضري و المكونات الكيميائية، أظهرت النتائج أن أعلى القيم المتوسطة كان في عدد الأوراق، الوزن الجاف للأوراق، مساحة الأوراق، قطر الساق، قطر caudex وزن جاف caudex، وطول الجذر، ووزن الجذر الجاف، و الكربو هيدر ات، و النيتزوجين، و الفوسفور و البوناسيوم، في

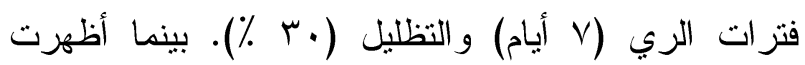
النتائج أن طول النبات و الكلوروفيل الكلي، تم الحصول عليهما في فتزات الري (V) أيام) و التظليل (. (Y٪). بالإضافة إلى ذلك، تم الحصول على محتوى البرولين في

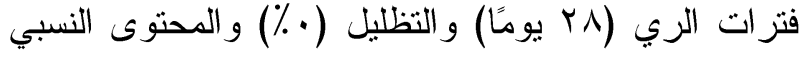

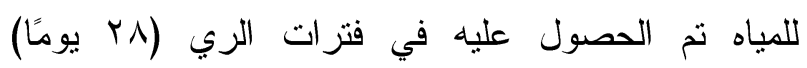
و التظليل (· • (\%).
أجريت هذه الدراسة في فرع البحوث بحديقة

أنطونيادس، معهد بحوث البساتين، الإسكندرية، مصر،

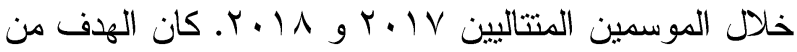
هذه الدراسة هو تقييم آثار فترات الري المختلفة ومعالجات التظليل على جودة نمو نباتات الزلوعة المزروعة في تربة خليط من الرمل والطين بنسبة (1:1) تحت ظروف الإسكندرية.

v) تم إجراء تجربة لاختبار تأثنير أربع فترات للري

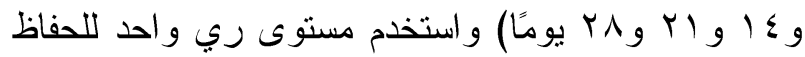
على رطوبة التربة عند السعة الحقلية للتربة المخلوطة

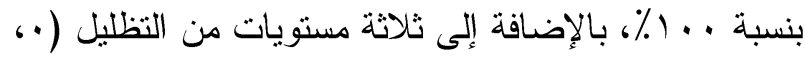

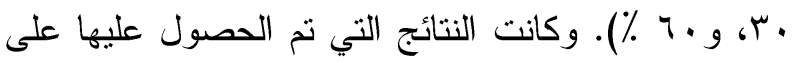

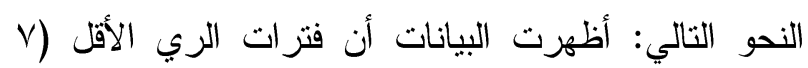

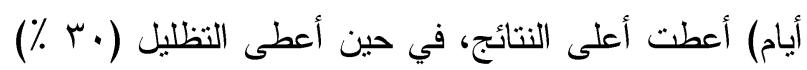
أعلى النتائج فى النمو الخضري و المكونات الكيميائية. فيما 